\title{
11. ORIGIN OF MASSIVE DOLOMITE, LEG 143, HOLE 866A, RESOLUTION GUYOT, MID-PACIFIC MOUNTAINS ${ }^{1}$
}

\author{
Peter G. Flood ${ }^{2}$ and Allan R. Chivas ${ }^{3}$
}

\begin{abstract}
Dolomite is ubiquitous in Barremian age sediments at depths below $1200 \mathrm{mbsf}$ in core from Hole 866A. Two distinct dolostones occur; one brown, the other white. The brown dolomite occurs over a 400 -m interval (1200-1620 mbsf), while the white dolomite is restricted to a 50-m interval (1250-1300 mbsf) enclosed within the brown dolomite. Dolostone rock textures include unimodal planar-s type, with nonmimically replaced to partially replaced allochems. The predominance of planar crystal boundaries indicates growth at low magnesium saturation and low temperatures. The dolomite is nonluminescent and ranges from highly calcian (41 mole\% $\mathrm{MgCO}_{3}$ ) to nearly stoichiometric in composition. Strontium, oxygen, and carbon stable isotopic compositions reveal two distinct pulses of dolomitization, both of which post-date the depositional age of the shallow-water carbonate sediments. Pulse I dolomitization could have occurred during the early Aptian or late Albian, after the shallow-water carbonate platform had subsided some 600 to $1200 \mathrm{~m}$. This dolomite displays $\delta^{18} \mathrm{O}_{P D B}$ values of -1.6 to +0.7 upcore; a $\delta^{13} \mathrm{C}_{P D B}$ value of +2.4 to +2.1 and an average ${ }^{87} \mathrm{Sr} /{ }^{86} \mathrm{Sr}$ value of 0.70735 . Pulse II dolomite displays a $\delta^{18} \mathrm{O}_{P D B}$ value of $+3.7, \delta^{13} \mathrm{C}_{P D B}$ value of +3.4 and an average ${ }^{87} \mathrm{Sr} /{ }^{86} \mathrm{Sr}$ value of 0.70822 . Pulse II is restricted to a narrow stratigraphic interval. Its age, at $24 \mathrm{Ma}$, is 100 m.y. younger than the depositional age and may correlate with events occurring about the time of the end of the Paleogene. Calculations, using the isotopic composition of seawater, of the temperature of the dolomite formation for pulse I range from $15^{\circ}$ to $30^{\circ} \mathrm{C}$. During pulse II, the temperature was $17^{\circ} \mathrm{C}$. Marine waters percolating through the guyot may be responsible for both pulse I and II dolomitization events. Geothermal endo-upwelling is one possible mechanism for driving the convective fluids through the subsiding carbonate platform, thereby promoting dolomitization.
\end{abstract}

\section{INTRODUCTION}

The origin of atoll dolomites has been a matter of debate since it was first reported by Cullis (1904) in the subsurface of Funafuti. It was Cullis who first inferred that seawater played a part in the transformation of a carbonate precursor by secondary replacement dolomite. Subsequent drillings on Pacific Ocean atolls (Kita-daito-jima, Enewetak, Midway, Collette, Niue, Aitutaki, and Mururoa) have provided evidence of sparse to pervasive dolomitization, with dolomitization taking place from the near-surface to, more commonly, deeper depths. Published literature reflects a considerable range of opinions regarding the origin of dolomite and the mechanism of dolomitization (Zenger and Dunham, 1988; Zenger et al., 1980; Land, 1985; Hardie, 1987; Aissaoui, 1988; Gunatilaka, 1987; Vahrenkamp and Swart, 1990; Braithwaite, 1991; Fowles, 1991; Vahrenkamp et al., 1988, 1991; Hein et al., 1992). Some authors (Schlanger, 1963; Saller, 1984; Aharon et al., 1987) have discussed in detail one plausible explanation for atoll dolomitization. This model involves convecting seawater driven by the thermal gradient existing within the carbonate sequence. This process has been referred to as the geothermal endoupwelling mechanism (Rougerie and Wauthy, 1988).

This study reports the results of a petrographic, geochemical, and ${ }^{18} \mathrm{O} /{ }^{16} \mathrm{O},{ }^{13} \mathrm{C} /{ }^{12} \mathrm{C}$, and ${ }^{87} \mathrm{Sr} /{ }^{86} \mathrm{Sr}$ isotopic study of the subsurface massive dolomites from the lower portion of Hole 866A, Leg 143, which was drilled on the northwestern margin (Lat. $21^{\circ} 19.953^{\prime} \mathrm{N}$, Long. $\left.174^{\circ} 18.844^{\prime} \mathrm{W}\right)$ of Resolution Guyot, Mid-Pacific Mountains.

\section{STRATIGRAPHIC OCCURRENCE OF DOLOMITE}

The 1691-m-thick sedimentary section penetrated by drilling into Hole 866 A contains a variety of shallow-water platform carbonates,

' Winterer, E.L., Sager, W.W., Firth, J.V., and Sinton, J.M. (Eds.), 1995. Proc. ODP. Sci. Results, 143: College Station, TX (Ocean Drilling Program).

${ }^{2}$ Department of Geology, University of New England, NSW 2351, Australia.

${ }^{3}$ Research School of Earth Sciences, Australian National University, Canberra, ACT 0200, Australia. including cyclic packstone-wackestone, oolitic grainstone, peloidal grainstone, oncoidal wackestone, and clay/organic-rich intervals (Jenkyns and Strasser, this volume; Strasser et al., this volume; ArnaudVanneau et al., this volume). While the presence of dolomite is first recorded at 500 mbsf in Section 143-866A-56R-CC and again at about $900 \mathrm{mbsf}$ in Sample 143-866A-98R-1, 104-106 cm, it is present almost continuously downhole below 1000 mbsf. Brown dolomite is ubiquitous in Barremian-age sediments from 1200 through $1620 \mathrm{mbsf}$ in Unit VII (Subunits VIIA through VIIC) and Unit VIII (Subunits VIIIA through VIIIB). White dolomite is restricted to a 50-m-thick interval from 1250 to 1300 mbsf enclosed within the brown dolomite. Petrographic descriptions of this basal sedimentary sequence can be found in the Initial Reports volume for Leg 143 (Sager, Winterer, Firth, et al., 1993) and are not repeated here.

\section{SAMPLES AND METHODS}

Several hundred thin sections were examined petrographically to identify the presence of dolomite. Twenty-six representative rock samples were selected for detailed study. Polished thin sections were prepared, and textural relationships were observed using a petrological microscope. Carbonate mineralogy was determined using $\mathrm{X}$-ray diffraction (University of New England, Armidale). Only monomineralic samples were analyzed for isotopic composition. Portions of selected samples were digested in $\mathrm{HCl} / \mathrm{HNO}_{3} / \mathrm{HClO}_{4}$ for trace-element analysis (inductively coupled plasma atomic emission spectroscopy [ICP-AES], Queensland University of Technology, Brisbane). Samples were examined for luminescence using cathodoluminescence equipment at the Research School of Earth Sciences, Canberra. Selected samples were analyzed using a JOEL-JSM 35 with microprobe attachment to determine the $\mathrm{Ca} / \mathrm{Mg}$ ratios (University of New England, Armidale). Oxygen and carbon isotopic measurements were performed at the Research School of Earth Sciences, Canberra using their standard technique (Chivas et al., 1993). Strontium isotopic compositions of 12 samples were measured by the Precise Radiogenic Isotope Services, Australian National University, Canberra. These measurements were performed using a Finnigan MAT 261 multicollector mass spectrometer in the 


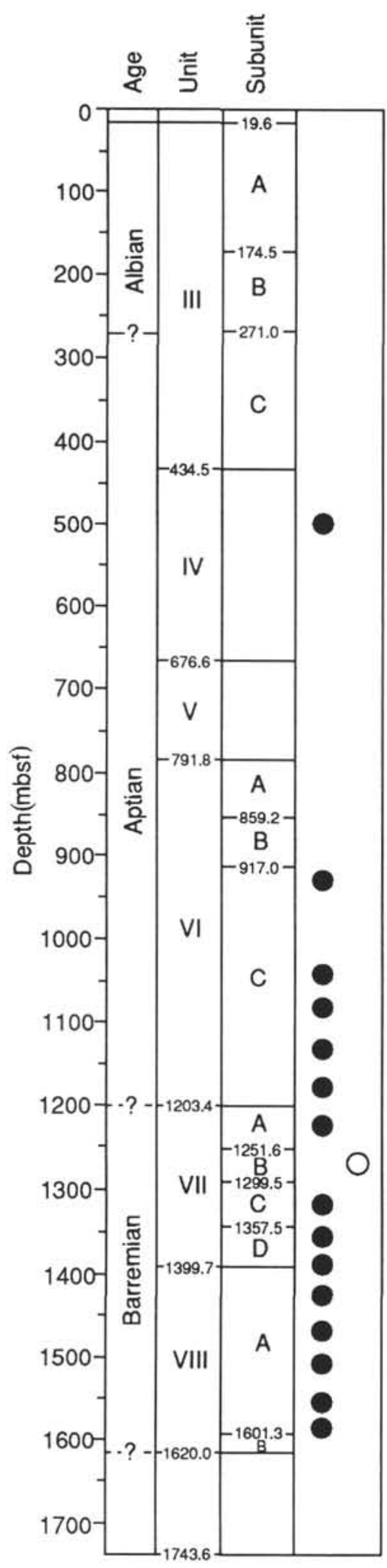

Figure 1. Simplified stratigraphy of Hole $866 \mathrm{~A}$ showing the distribution of dolomite (filled circles $=$ brown dolomite; unfilled circles $=$ white dolomite). static mode. The isotopic ratios have been normalized to ${ }^{86} \mathrm{Sr} /{ }^{88} \mathrm{Sr}=$ 0.1194. Standards SRM 987 and EN-1 were run in conjunction with the samples.

\section{DOLOSTONE TEXTURES}

Two distinctly different dolostones, a brown type and a white type, can be recognized in cores from Hole 866A (Fig. 1). After nucleation, dolomite crystallization continues until a brown, fine-to-medium grain-sized, in part sucrosic, dolostone is formed (Pl. 1, Figs. 1 and 2). Crystal size of the brown dolostone is usually less than $5 \mu \mathrm{m}$. The second type, the white dolostone, can be observed in Cores 143$866 \mathrm{~A}-133 \mathrm{R}$ through $-137 \mathrm{R}$. This dolostone is coarsely crystalline (up to $10 \mu \mathrm{m}$-sized crystals), and it exhibits well-developed intercrystalline and moldic porosity, while preserving the original texture. All crystals are euhedral to anhedral and exhibit planar boundaries. A variety of diagenetic textures can be observed using the classification scheme of Sibley and Gregg (1987). These textures include unimodal planar-s types with prominent sucrosic textures and bimodal planar-s types with nonmimically replaced allochems (peloids) having secondary partial void fillings of polymodal planar-s dolomite; some large allochems (e.g., oncolites) display partial replacement by unimodal planar-e texture dolomite. Occasionally, multiple phases of dolomitization were observed (e.g., Sample 143-866A-159R-3, 82-84 $\mathrm{cm}$; Pl. 1, Fig. 4). The predominance of planar crystal boundaries having faceted crystal faces indicates development at low temperatures $\left(<50^{\circ} \mathrm{C}\right)$ and low saturation (Sibley and Gregg, 1987).

A large proportion of the textures are replacive. An early phase of dispersed dolomitization is evident as patchy nucleation sites within peloids, ooids, and bioclasts. However, dolomite crystals of the massive dolostone indicate post-compaction formation (Pl. 2, Fig. 1; Pl. 3, Fig. 2). Ghost outlines of preexisting allochems can be observed in some coarse-grained dolostones.

\section{GEOCHEMISTRY}

Eighteen microprobe analyses of the dolomite indicate that the composition ranges from $\mathrm{Ca}_{1.18} \mathrm{Mg}_{0.82}\left(\mathrm{CO}_{3}\right)_{2}$ for the dark portions of crystals to $\mathrm{Ca}_{1.06} \mathrm{Mg}_{0.94}\left(\mathrm{CO}_{3}\right)_{2}$ for the light-colored portions. The dolomites are nearly stoichiometric with regard to their composition. The dark portions of individual crystals correspond to the position of skeletal ghosts, while the lighter portions correspond to the position of replaced intergranular cement or subsequent void infillings (Pls. $2-4)$. There does not appear to be any marked compositional difference, other than iron content, in the composition of either the brown or the white dolomites (Table 1). ICP-AES analyses (Table 2) of the brown dolomite showed that $\mathrm{Mn}$ content is low, while $\mathrm{Fe}$ content is variable. The white dolomite contains $39 \mathrm{ppm} \mathrm{Fe}$, whereas the brown dolomite exhibits considerable variation (92-2051 ppm Fe). Cathodoluminescence studies showed that these dolomites are nonluminescent. This result is in agreement with their low Mn content. Clearly, no $\mathrm{Mn}$ from waters percolating through the volcanic pedestal has been added to the dolomitizing solutions. The similarity of the $\mathrm{Sr}$ values of the two dolomite types also indicates that the $\mathrm{Sr} / \mathrm{Ca}$ ratio of the precipitating waters may have been similar (assuming a similar major-element composition).

\section{STABLE ISOTOPE RESULTS \\ Oxygen and Carbon Isotopes}

The oxygen and carbon isotope compositions of the dolomites are shown in Table 3. The $\delta^{18} \mathrm{O}_{P D B}$ values range from -1.6 to +3.7 . The brown dolomite values vary between -1.6 and +0.7 , and they display a positive trend in values uphole from -1.6 to +0.7 . The samples of white dolomite display a constant value of +3.7 . The $\delta^{13} \mathrm{C}_{P D B}$ values for the brown dolomites ranges in value from +2.1 to +2.8 , with no apparent trend within the hole. The value for the white dolomite is 
Table 1. Composition of trace elements (ICP-AES) of representative samples of two dolomite types.

\begin{tabular}{|c|c|c|}
\hline $\begin{array}{l}\text { Sample: } \\
\text { Depth (mbsf): }\end{array}$ & $\begin{array}{c}\text { Brown dolomite } \\
143-866 \mathrm{~A}-162 \mathrm{R}-01,0-3 \mathrm{~cm} \\
1531\end{array}$ & $\begin{array}{c}\text { White dolomite } \\
143-866 \text { A-133R-01, 145-147 cm } \\
1252\end{array}$ \\
\hline $\mathrm{Sr}$ & 106 & 109 \\
\hline $\mathrm{Ba}$ & $<1$ & $<1$ \\
\hline $\mathrm{Mn}$ & 11 & $<10$ \\
\hline $\mathrm{Fe}$ & 110 & 39 \\
\hline $\mathrm{Zn}$ & 7 & 33 \\
\hline $\mathrm{Cu}$ & 2 & 3 \\
\hline
\end{tabular}

Note: Values of trace elements in parts per million.

uniform at +3.4 . Evidence exists to show that the isotopic composition of seawater has changed through time, with ancient seawater having different $\delta^{18} \mathrm{O}$ and $\delta^{13} \mathrm{C}$ values from present-day values (Lohmann, 1988). This might explain the difference in the carbon isotopic composition between the two pulses of dolomite. The lower-than-today oxygen isotopic composition of ancient seawater was taken into account when calculating temperature of dolomite formation.

\section{Paleotemperature of Dolomite Formation}

Land (1985, p. 118) published an equation for calculating the temperature of dolomite formation, based on $\delta^{18} \mathrm{O}_{P D B}$ values. This equation is

$$
\begin{aligned}
\mathrm{T}\left({ }^{\circ} \mathrm{C}\right) & =16.4-4.3\left[\left(\delta^{18} \mathrm{O} \text { dol. }-3.8\right]-\delta \text { water }\right) \\
& +0.14\left(\left[\delta^{18} \mathrm{O} \text { dol. }-3.8\right]-\delta \text { water }\right)^{2} .
\end{aligned}
$$

If differences in seawater isotopic compositions throughout time are allowed for, the formation temperature (using a $\delta^{18} \mathrm{O}$ value of -2 for seawater approximately 100 Ma; see Lohmann, 1988, p. 67, fig. 2.8) of pulse I brown dolomites ranges from $15^{\circ}$ to $30^{\circ} \mathrm{C}$. The formation temperature of pulse II white dolomite is approximately $17^{\circ} \mathrm{C}$. The formation temperature of the white dolomite approximates the shipboard recorded temperature of $13.6^{\circ} \mathrm{C}$, measured at $1671.5 \mathrm{mbsf}$ (Sager, Winterer, Firth, et al., 1993, Fig. 59).

\section{Strontium Isotopes}

Two distinct strontium values can be observed (Table 3). Those of Core $143-866 \mathrm{~A}-133 \mathrm{R}$, which have $\mathrm{a}^{87} \mathrm{Sr} /{ }^{86} \mathrm{Sr}$ ratio of 0.70822 , and the other dolomites, which have a ratio of approximately 0.70735 . The difference between the two types of dolomites clearly is evident when calculated as $\Delta \mathrm{Sr}$ values.

\section{${ }^{87} \mathrm{Sr} /{ }^{86} \mathrm{Sr}$ Age Calculations}

Comparison of the ${ }^{87} \mathrm{Sr} /{ }^{86} \mathrm{Sr}$ isotopic record of limestones from Hole 866A (Jenkyns et al., this volume) enables one to place constraints upon the timing of dolomitization. The strontium-isotope seawater curve shows that ${ }^{87} \mathrm{Sr} /{ }^{86} \mathrm{Sr}$ ratio has oscillated and then increased during the past 140 m.y. (DePaolo and Ingram, 1985; Elderfield, 1986; Hess et al., 1986; Jenkyns et al., this volume; Koepnick et al., 1985). Notwithstanding the constraints on interpretation of ${ }^{87} \mathrm{Sr} /{ }^{86} \mathrm{Sr}$ ratios in dolomites (Vahrenkamp and Swart, 1988), it is possible to estimate the age of the dolomitization using published curves (e.g., Jones, 1992; Jenkyns et al., this volume, Cretaceous curve; McArthur, 1991, Paleogene curve; McArthur, 1993, combined curve) or the equations developed by McKenzie et al. (1993, Table 3). The brown dolomite may have formed any time between 120 and $105 \mathrm{Ma}$ (Jenkyns et al., this volume), while the white sucrosic dolomite (Core 143-866A-133R) is definitely much younger, having formed about $24 \mathrm{Ma}$.

As Vahrenkamp and Swart (1988) pointed out, the influence of precursor age and mineralogy (calcite vs. aragonite) on the Sr-isotopic signature of resultant dolomite will be such that the apparent dolomi-
Table 2. Mn, Fe, and Zn analyses (ICP-AES) of dolomites from Leg 143,

\begin{tabular}{|c|c|c|c|c|}
\hline $\begin{array}{l}\text { Core, section, } \\
\text { interval }(\mathrm{cm})\end{array}$ & $\begin{array}{l}\text { Depth } \\
\text { (mbsf) }\end{array}$ & $\begin{array}{c}\mathrm{Mn} \\
\text { (ppm) }\end{array}$ & $\begin{array}{c}\mathrm{Fe} \\
(\mathrm{ppm})\end{array}$ & $\underset{(\mathrm{ppm})}{\mathrm{Zn}}$ \\
\hline $\begin{array}{l}\text { 143-866A- } \\
125 \mathrm{R}-1,42-47 \\
133 \mathrm{R}-1,145-147^{*} \\
\text { 139R-1,32-34 } \\
\text { 144R-3,50-52 } \\
\text { 146R-1, 111-113 } \\
\text { 148R-3,12-14 } \\
\text { 154R-2, 112-113 } \\
\text { 162R-3,0-3 } \\
\text { 164R-2, 104-107 } \\
\text { 170R-2, 52-53 }\end{array}$ & $\begin{array}{l}1175 \\
1252 \\
1310 \\
1361 \\
1377 \\
1398 \\
1456 \\
1534 \\
1554 \\
1611\end{array}$ & $\begin{array}{r}6 \\
<10 \\
5 \\
6 \\
25 \\
49 \\
6 \\
11 \\
7 \\
27\end{array}$ & $\begin{array}{r}122 \\
39 \\
132 \\
121 \\
579 \\
2051 \\
92 \\
110 \\
268 \\
1536\end{array}$ & $\begin{array}{c}\mathrm{Nd} \\
33 \\
\mathrm{Nd} \\
\mathrm{Nd} \\
\mathrm{Nd} \\
\mathrm{Nd} \\
\mathrm{Nd} \\
7 \\
\mathrm{Nd} \\
\mathrm{Nd}\end{array}$ \\
\hline
\end{tabular}
Hole 866A.

Notes: " = Sample $133 \mathrm{R}$ is white dolomite; remainder are brown sucrosic dolomite. $\mathrm{Nd}$ $=$ not determined.

tization age is likely, but not necessarily, equal to the actual dolomitization age, considering mass balance calculations. In environments free of exotic $\mathrm{Sr}$ sources, age estimates are likely to be maximum ages. Less radiogenic strontium, whose source is the basement volcanics or the precursor sedimentary carbonate rocks, would tend to make the apparent age of dolomitization older than its actual age. However, as a considerably large volume of water is involved in the dolomitization process (see Vahrenkamp and Swart, 1988; Paull et al., this volume), the apparent and actual ages of dolomitization should be the same.

\section{DISCUSSION}

Petrographic and isotopic studies of the dolomite present in the lower part of the cores from Hole 866A suggest the presence of two distinct pulses of dolomitization. Pulse I occurred between 120 to 105 $\mathrm{Ma}$, as a Sr value of about 0.70735 indicates an age of early Aptian or late Albian, according to the Jones (1992) and Jenkyns et al. (this volume) curve. It produced an even-textured brown dolostone. Nucleation of crystal growth commenced within both the allochems and the cement/matrix. Near-surface dolomitization may be a possible process that occurred just after deposition of the carbonate sediments. However, the age of pulse I dolomites indicates that some other mechanism produced the dolomitization event. This may have been associated with aragonite and calcite dissolution as the guyot subsided. Below about $1000 \mathrm{mbsl}$, the modern Pacific Ocean water becomes undersaturated with respect to first aragonite and then calcite (Scholle et al., 1983). As the shallow-water carbonate platform subsided on the sinking seamount, a stage was reached where the aragonitic skeletal elements began to dissolve and to produce enhanced porosity within the sediments (PI. 2, Fig. 2). At even greater depths, the calcitic components also underwent dissolution, resulting in the original texture of the carbonates being reversed. Grains became voids, and voids became cemented with dolomite (see Pl. 1).

Pulse II (white sucrosic dolomite) formed at about $24 \mathrm{Ma}$. This event corresponded approximately to the time of the Paleogene/ Neogene boundary. No original aragonite or calcite fragments were observed in this dolostone. The timing of this second pulse of dolomitization may coincide with events associated with a decrease in sea level during the late Oligocene (Schlanger and Premoli Silva, 1986) and the transgression following. Changes in ocean circulation patterns associated with the change from "greenhouse" to "icehouse" conditions and associated fluctuations of sea level may have been one mechanism capable of altering the hydrodynamic circulation through the carbonate platform, thereby promoting increased seawater flux through the platform. McKenzie et al. (1993) suggested that synchroneity of dolomitization events within carbonate platforms may reflect a global process driven by a common cause, such as eustatic sea-level control. This suggestion warrants further consideration. It is of interest to record that the stratigraphic arrangement of the dolomitization is such that the younger dolomite is both overlain and under- 
Table 3. Isotopic analyses of dolomites from Leg 143, Hole 866A.

\begin{tabular}{|c|c|c|c|c|c|c|}
\hline $\begin{array}{l}\text { Core, section, } \\
\text { interval }(\mathrm{cm})\end{array}$ & $\begin{array}{l}\text { Depth } \\
\text { (mbsf) }\end{array}$ & $\delta^{18} \mathrm{O}_{P D B}$ & $\delta^{13} C_{P D B}$ & ${ }^{87} \mathrm{Sr} /{ }^{86} \mathrm{Sr}^{3}$ & $\pm 2 \sigma$ & $\pm \Delta \mathrm{Sr}^{\mathrm{b}}$ \\
\hline \multicolumn{7}{|l|}{$143-866 \mathrm{~A}-$} \\
\hline $130 \mathrm{R}-2,17-19 \mathrm{~cm}$ & 1224 & +0.7 & +2.4 & 0.707394 & 0.000015 & -2.45 \\
\hline 133R-1, 145-147 & 1252 & +3.7 & +3.4 & 0.708215 & 0.000015 & -1.29 \\
\hline $133 \mathrm{R}-2,19-22$ & 1253 & +3.7 & +3.4 & 0.708223 & 0.000010 & -1.28 \\
\hline $133 \mathrm{R}-3,50-52$ & 1255 & +3.7 & +3.3 & 0.708227 & 0.000015 & -1.27 \\
\hline $148 \mathrm{R}-1,44-46$ & 1396 & -0.4 & +2.1 & 0.707363 & 0.000016 & -2.49 \\
\hline $159 \mathrm{R}-3,82-84$ & 1505 & -0.6 & +2.4 & 0.707337 & 0.000010 & -2.53 \\
\hline $160 \mathrm{R}-1,70-73$ & 1512 & -0.7 & +2.2 & 0.707397 & 0.000010 & -2.44 \\
\hline $162 \mathrm{R}-2,139-141$ & 1534 & -0.6 & +2.5 & 0.707288 & 0.000015 & -2.60 \\
\hline $162 \mathrm{R}-3,0-3$ & 1535 & -1.1 & +2.3 & 0.707310 & 0.000016 & -2.57 \\
\hline $163 R-1,16-17$ & 1540 & -1.0 & +2.1 & 0.707350 & 0.000016 & -2.51 \\
\hline $164 R-1,94-96$ & 1554 & -1.0 & +2.8 & 0.707383 & 0.000012 & -2.46 \\
\hline $166 \mathrm{R}-2,109-122$ & 1572 & -1.6 & +2.4 & 0.707323 & 0.000016 & -2.55 \\
\hline
\end{tabular}

Note: Pulse II white dolomites in bold.

a ${ }^{87} \mathrm{Sr} /{ }^{86} \mathrm{Sr}$ ratios normalized to ${ }^{88} \mathrm{Sr} /{ }^{86} \mathrm{Sr}=0.1194$.

${ }^{\mathrm{b}} \Delta \mathrm{Sr}=1000 \cdot\left(\left[{ }^{87} \mathrm{Sr}_{\mathrm{m}} / 0.709130\right]-1\right)$ and $\Delta$ values calculated relative to $\mathrm{EN}-1$ standard: $\mathrm{EN}-10.709130$ \pm 0.000010 ( 9 analyses).

lain by the older dolomite. A similar situation was found at Hole 812 , Leg 133 (McKenzie et al., 1993).

Dolomite formation during pulse I occurred within the temperature range of $15^{\circ}$ to $30^{\circ} \mathrm{C}$. During pulse II dolomitization, the temperature was $17^{\circ} \mathrm{C}$. The temperature existing about $24 \mathrm{Ma}$ approximates the present-day measured downhole temperature.

Land (1985) proposed that seawater provided an inexhaustible reservoir of $\mathrm{Mg}^{++}$responsible for massive dolomitization. One process of dolomitization, referred to as the Kohout model and modeled by Simms (1984), has been substantiated by Saller (1984), Aharon et al. (1987), and many others. Fluid flow through a carbonate platform can be driven by geothermal endo-upwelling (Rougerie and Wauthy, 1988; 1993; Rougerie et al., 1992). Dolomitization could be associated with endo-upwelling.

In addition to the possibility of near-surface dolomitization occurring in the shallow-water carbonate sequence encountered in Hole $866 \mathrm{~A}$, a second mechanism for dolomitization is postulated to explain the massive brown and white dolomites of pulses I and II, respectively. This model involves a gradually subsiding shallow-water carbonate sequence atop a seamount, with the basic conditions favorable for dolomitization being

1. A permeable carbonate substrate,

2. A contiguous deep ocean containing an abundant source of $\mathrm{Mg}^{++}$ions, and

3. A heat-generating basement that provides a geothermally driven convective process.

\section{ACKNOWLEDGMENT}

We thank J.A. McKenzie and V.C. Vahrenkamp for constructive reviews of the manuscript. X-ray diffraction analyses were undertaken by J. Bedford, ICP-AES analyses were made by W. Kwieien, and $\mathrm{Sr}$ isotopic analyses were provided by C.M. Fanning. X. Wang and J. Cali produced the stable-isotope analyses. This research has been supported by the Australian Research Council (Grant No. A39230803 to P.G. Flood).

\section{REFERENCES*}

Aharon, P., Socki, R.A., and Chan, L., 1987. Dolomitization of atolls by sea water convection flow: test of a hypothesis at Niue, South Pacific. J. Geol., 95:187-203.

"Abbreviations for names of organizations and publications in ODP reference lists follow the style given in Chemical Abstracts Service Source Index (published by American Chemical Society).
Aissaoui, D.M., 1988. Magnesium calcite cements and their diagenesis: dissolution and dolomitization, Mururoa Atoll. Sedimentology, 35:821-841.

Braithwaite, C.J.R., 1991. Dolomites, a review of origins, geometry and textures. Trans. R. Soc. Edinburgh: Earth Sci., 82:99-112.

Chivas, A.R., De Deckker, P., Cali, J.A., Chapman, A., Kiss, E., and Shelley, J.M.G., 1993. Coupled stable-isotope and trace-element measurements of lacustrine carbonates as paleoclimatic indicators. In Swart, P.K., Lohmann, K.C., McKenzie, J., and Savin, S. (Eds.), Climate Change in Continental Isotopic Records. Geophys. Monogr., Am. Geophys. Union, 78:113-121.

Cullis, C.G., 1904. The mineralogical changes observed in cores from the Funafuti borings. In Bonney, T.G. (Ed.), The Atoll of Funafuti. R. Soc. London, 392-420.

DePaolo, D.J., and Ingram, B.L., 1985. High-resolution stratigraphy with strontium isotopes. Science, 227:938 - 940.

Elderfield, H., 1986. Strontium isotope stratigraphy. Palaeogeogr., Palaeoclimatol., Palaeoecol., 57:71-90.

Fowles, J., 1991. Dolomite: the mineral that shouldn't exist. New Sci., 132:3842.

Gunatilaka, A., 1987. The dolomite problem in the light of recent studies. Mod. Geol., 11:311-324.

Hardie, L.A., 1987. Dolomitization: a critical view of some current views. J. Sediment. Petrol., 57:166-183.

Hein, J.R., Gray, S.C., Richmond, B.M., and White, L.D., 1992. Dolomitization of quaternary reef limestones, Aitutaki, Cook Islands. Sedimentology, 39:645-661.

Hess, J., Bender, M.L., and Schilling, J.-G., 1986. Seawater ${ }^{87} \mathrm{Sr} /{ }^{86}$ Sr evolution from Cretaceous to Present-applications to paleoceanography. Science, 231:979-984.

Jones, C.E., 1992. The strontium isotopic composition of Jurassic and Early Cretaceous seawater [Ph.D. thesis]. Univ. of Oxford.

Koepnick, R.B., Burke, W.H., Denison, R.E., Hetherington, E.A., Nelson, H.F., Otto, J.B., and Waite, L.E., 1985. Construction of the seawater ${ }^{87} \mathrm{Sr} /{ }^{86} \mathrm{Sr}$ curve for the Cenozoic and Cretaceous: supporting data. Chem. Geol. (Isotope Geosci. Sect.), 58:55-81.

Land, L.S., 1985. The origin of massive dolomite. J. Geol. Educ., 33:112-125.

Lohmann, K.C., 1988. Geochemical patterns of meteoric diagenetic systems and their application to studies of paleokarst. In James, N.P., and Choquette, P.W. (Eds.), Paleokarst: New York (Springer-Verlag), 58-80.

McArthur, J.M., 1991. Strontium-isotope stratigraphy. Geol. Today, Earth Reference 5, 7:i-iv.

, 1993. Strontium isotope stratigraphy in and out of ODP. UK ODP Newsl., 16:8-9.

McKenzie, J.A., Isern, A., Elderfield, H., Williams, A., and Swart, P., 1993. Strontium isotope dating of paleoceanographic, lithologic, and dolomitization events on the northeastern Australian margin, Leg 133. In McKenzie, J.A., Davies, P.J., Palmer-Julson, A., et al., Proc. ODP, Sci. Results, 133: College Station, TX (Ocean Drilling Program), 489-498.

Rougerie, F., Fagerstrom, J.A., and Andrie, C., 1992. Geothermal endo-upwelling: a solution to the reef nutrient paradox. Cont. Shelf Res., 12:785-798.

Rougerie, F., and Wauthy, B., 1988. The endo-upwelling concept: a new paradigm for solving an old paradox. Proc. 6th Int. Coral Reef Symp., $3: 21-26$. 
1993. The endo-upwelling concept: from geothermal convection to reef construction. Coral Reefs, 12:19-30.

Sager, W.W., Winterer, E.L., Firth, J.V., et al., 1993. Proc. ODP, Init. Repts., 143: College Station, TX (Ocean Drilling Program).

Saller, A.H., 1984. Petrologic and geochemical constraints on the origin of subsurface dolomite, Enewetak Atoll: an example of dolomitization by normal seawater. Geology, 12:217-220.

Schlanger, S.O., 1963. Subsurface geology of Eniwetak Atoll. Geol. Surv. Prof. Pap. U.S., 260-BB:991-1066.

Schlanger, S.O., and Premoli Silva, I., 1986. Oligocene sea-level falls recorded in mid-Pacific atoll and archipelagic apron settings. Geology, 14:392-395.

Scholle, P.A., Arthur, M.A., and Ekdale, A.A., 1983. Pelagic environments. In Scholle, P.A., Bebout, D.G., and Moore, C.H. (Eds.), Carbonate Depositional Environments. AAPG Mem., 33:620-691.

Sibley, D.F., and Gregg, J.M., 1987. Classification of dolomite rock textures. J. Sediment. Petrol., 57:967-975.

Simms, M., 1984. Dolomitization by groundwater-flow systems in carbonate platforms. Trans. Gulf Coast Assoc. Geol. Soc., 34:411-420.

Vahrenkamp, V.C., and Swart, P.K., 1990. New distribution coefficient for the incorporation of strontium into dolomite and its implications for the formation of ancient dolomites. Geology, 18:387-391.
Vahrenkamp, V.C., Swart, P.K., and Ruiz, J., 1988. Constraints and interpretation of ${ }^{87} \mathrm{Sr} /{ }^{86} \mathrm{Sr}$ ratios in Cenozoic dolomites. Geophys. Res. Lett., 15:385-388.

, 1991. Episodic dolomitization of late Cenozoic carbonates in the Bahamas: evidence from strontium isotopes. J. Sediment. Petrol., 61:10021014.

Zenger, D.H., and Dunham, J.B., 1988. Dolomitization of Siluro-Devonian limestones in a deep core $(5,350 \mathrm{~m})$, Southeastern New Mexico. In Shukla, V., and Baker, P.A. (Eds.), Sedimentology and Geochemistry of Dolostones. Spec. Publ.-Soc. Econ. Paleontol. Mineral., 43:161-174.

Zenger, D.H., Dunham, J.B., and Ethington, R.L. (Eds.), 1980. Concepts and Models of Dolomitization. Spec. Publ.-Soc. Econ. Paleontol. Mineral., 28.

Date of initial receipt: 15 November 1993

Date of acceptance: 1 June 1994

Ms 143SR-229 


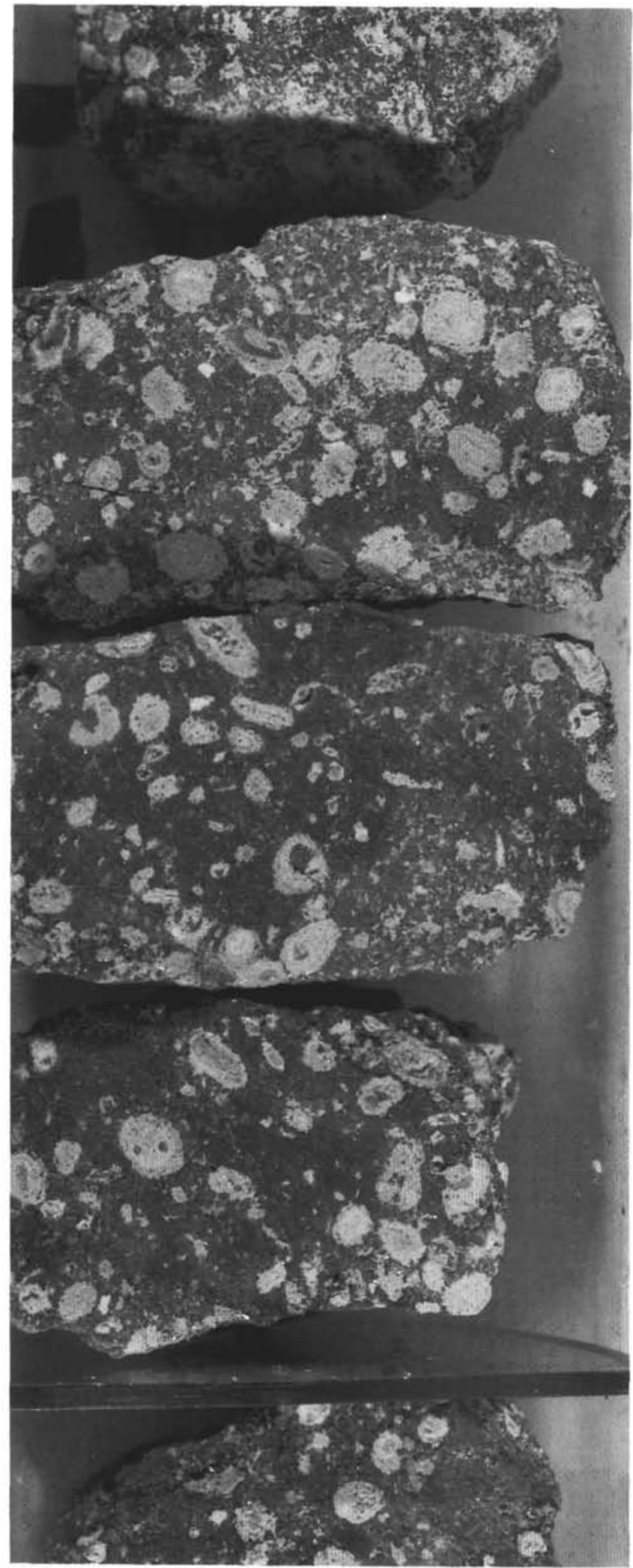

1

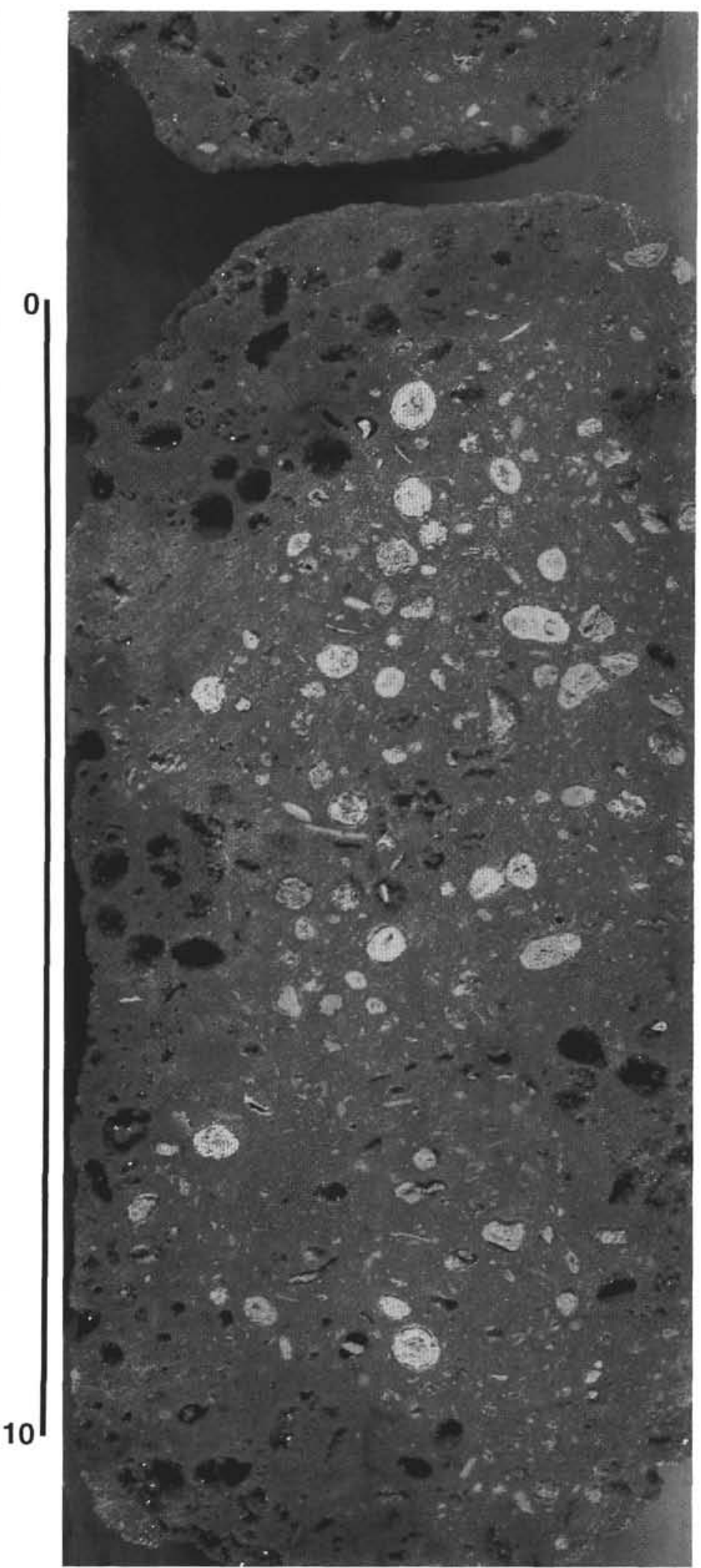

2

Plate 1. Stages in the dolomitization process. 1. Brown sucrosic dolomitic groundmass and scattered unaltered calcitic white oncoid bioclasts (core photograph Section 143-866A-159R-1, 20-34 cm). 2. Similar to 1, but with calcitic bioclast dissolution leaving prominent moldic porosity. Some parts of this core contain no original calcitic bioclasts (core photograph Section 143-866A-159R-3, 70-84 cm). 

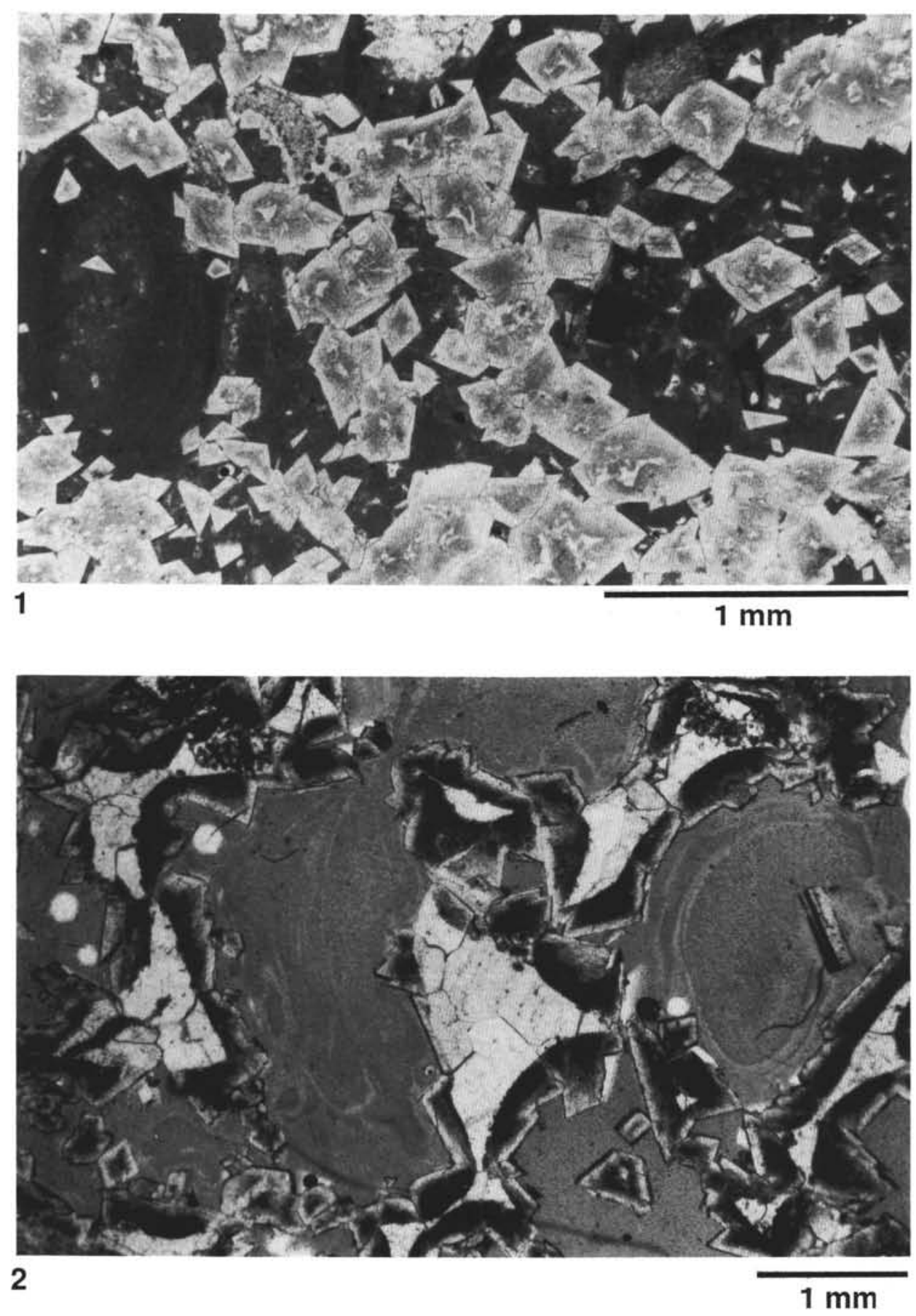

Plate 2. Photomicrographs of dolomitized limestones. 1. Incipient dolomitization at multiple nucleation sites displaying variable crystal sizes. Dolomitization is post-deposition (Sample 143-866A-159R-1, 22-25 cm). 2 . Complete dolomitization displaying intergranular cements now dolomitized and original bioclastic fragments now dissolved (inversion of porosity). This rock displays up to $60 \%$ porosity. Ghosts of original allochems preserved as the dark outlines (Sample 143-866A-166R-2, 109-112 cm). Scale bars are $1 \mathrm{~mm}$ in each case. 

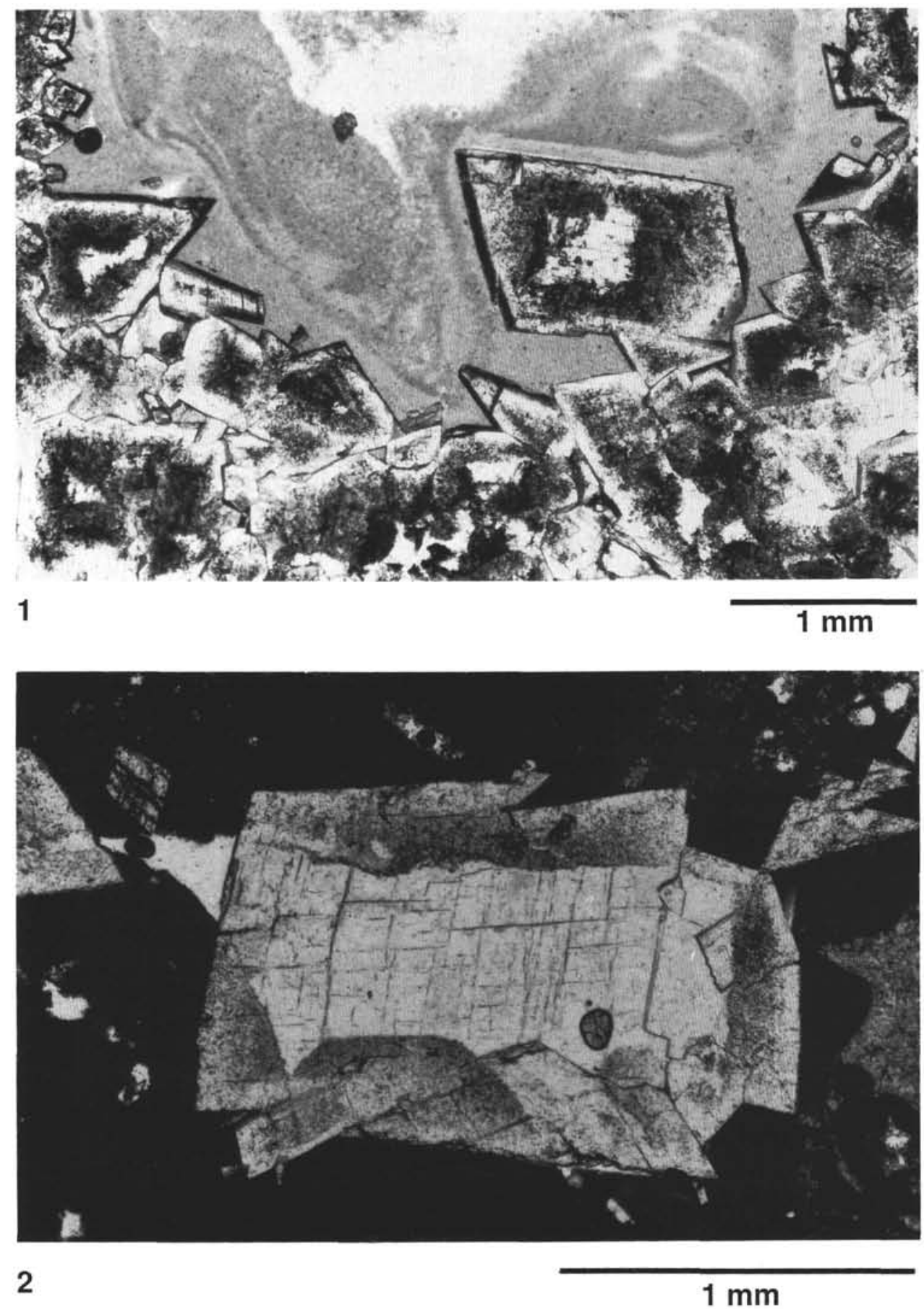

Plate 3. Photomicrographs of dolomitized limestones. 1. Equigranular mosaic of dolomite crystals displaying original skeletal element ghosts, now dark, and later stage overgrowths by dolomite (Sample 143-866A-166R-3, 0-3 cm). 2. Euhedral dolomite crystal containing ghosts of original ooids (Sample 143-866A-159R-1, 22-25 cm). Scale bars are $1 \mathrm{~mm}$ in each case. 

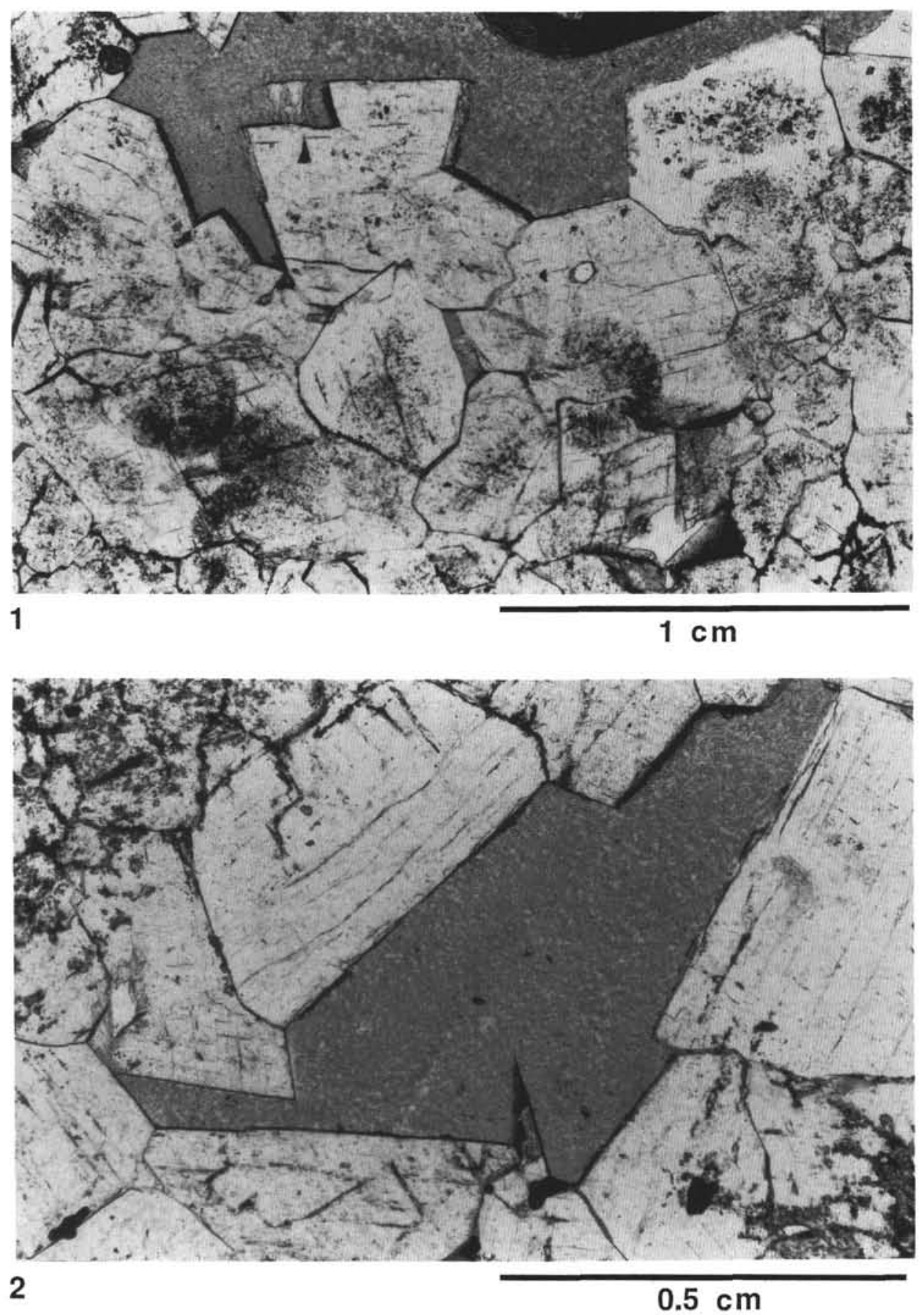

Plate 4. Photomicrographs of dolomitized limestones. 1. Equigranular mosaic of white sucrosic dolomite crystals containing darker ghosts of preexisting allochems, mainly ooids (Sample 143-866A-133R-1, 145-147 $\mathrm{cm}$ ). This is a sample of the "younger" dolomite. 2. Equigranular mosaic of brown sucrosic dolomite filling in a void (Sample 143-866A-160R-1, 70-73 cm). This is a sample of the "older" dolomite. Scale bars are 1 and 0.5 $\mathrm{mm}$, respectively. 